\title{
Prevalence and Predictors of Burnout Syndrome among Medical Students of Cairo University
}

\author{
Monira M. ElKholy, Eman T. El-Sayed, Amal S. Sedrak, Nihal Abdel Raouf \\ Abdelrahman
}

Public Health Department, Faculty of Medicine, Cairo University, Cairo

Received: August, 2018 Accepted: November, 2018

\begin{abstract}
Background: Medical students and trainees experience burnout, syndrome portrayed by emotional exhaustion, cynicism and low sense of professional efficacy. Burnout can demolish professionalism and contribute to medical errors. Objective: to estimate the prevalence of burnout syndrome among medical students, to explore the association between different demographic and lifestyle variables and burnout syndrome. Method: A cross-sectional study design was conducted on a convenient sample of 350 students from the first, fourth and sixth academic grades. A structured self-administrated questionnaire was used for socio-demographic and lifestyle data collection in addition to Maslach burnout inventory- student survey (MBI-SS). Results: About $38.1 \%$ of the study population experienced high emotional exhaustion subscale, whereas students suffering from high cynicism subscale and low professional efficacy subscale represented $32.4 \%$ and $31 \%$ respectively of the study population. Significant association was highlighted between high emotional exhaustion and female students getting inadequate sleep, suffering from chronic illness, and having little or no leisure time. High cynicism was significantly associated with being an Egyptian student or living with family. Low professional efficacy was significantly associated with low academic score, having little or no leisure time and lack of physical activity. Worrying about choosing a specialty and future income ranked the most significant predictors for high emotional exhaustion and cynicism scores. Conclusion: Tremendous efforts ought to be applied to investigate stressors faced by the students and to embrace Burnout preventive and Interventional measures accordingly.
\end{abstract}

Keywords: Burnout syndrome, medical students, emotional exhaustion, cynicism

Corresponding Author : Amal Samir E-mail address: amalnewlife82@gmail.com

\section{Introduction}

In recent decades considerable attention has been paid to mental health of medical students. $^{1}$ An extravagant number of tasks require schedules and challenging responsibilities to learn about and care for human beings and became potential triggers or synchronized causes of emotional disturbances. $^{2}$

These stressors create psychological toxicity that affects medical students' training and activities; such circumstances are also encountered in other health professions' courses. ${ }^{3}$ Such stressors can lead to several disastrous consequences such as anxiety, despair, impaired competency, inefficient academic performance, and frequent medical errors from medical schools ${ }^{4}$ and may end up with Burnout syndrome.5

Burnout is portrayed as a syndrome resulting from the interaction between chronic stress at work and individual factors, and its symptoms and signs are grouped into emotional exhaustion (EE), 
depersonalization (DE) or skepticism, and reduced professional satisfaction (PS). BS differs from depression because it is workplace-specific, whereas depression extends to other nonprofessional contexts. ${ }^{6-8}$ Numerous studies have shown high incidence of Burnout in health care professionals 9,10 as well as in individuals whose activities are psychologically similar to work, such as students. ${ }^{11}$

Burnout among healthcare workers could entail all job categories, including nurses and nursing assistants, physicians, and administrative staff. ${ }^{12}$ Higher prevalence of burnout among primary care staff was reported in two Spanish studies. The study conducted in the Navarro region of Spain $^{13}$ revealed that $39.3 \%$ of subjects showed a significant degree of at least one of the three burnout syndrome's dimensions. This was judged against $46.2 \%$ of the $2^{\text {nd }}$ study population (carried out in the Barcelona region) who presented with at least one of the three components. ${ }^{14}$ Administrative staff $(80 \%)$ and family physicians $(41.3 \%)$ were the most affected professions by burnout according to these two studies.

The principal measurement for assessing burnout is the Maslach Burnout Inventory Human Services Survey (MBIHSS).5 It went through three revisions. MBI-HSS was designed for professionals working in people-centered services, such as doctors, nurses, psychologists and health professions' students. ${ }^{15}$

It is worth mentioning that various studies featured many risk factors among medical students, especially after facing numerous difficulties, such as having trouble adjusting to the start of the course work, aggressive placement tests, excessive workload, high level of educational demand, and lack of time for leisure or family and friends. Also, the decision of having a particular specialty and agonizing over the salary significantly contribute to that stress faced by medical students. ${ }^{16}$ It was also reported by several researchers that the students' mental health critically deteriorates as courses progress, with increasing incidence of burnout among those entering the more advanced phases of their education. ${ }^{17,18}$

Impending consequences include poor work performance, alcohol and drug dependence/abuse, an increased risk of cardiovascular diseases, sleep disorders, negligence of personal health and risky behavior. ${ }^{19}$

During the past few decades, there was a growing concern worldwide for understanding the burnout syndrome. ${ }^{20}$

Therefore, looking into early identification of Burnout Syndrome is expected to empower the reception of preventive measures to be imparted to the scientific network. However, there is scarcity of studies conducted in Egypt, focusing on burnout syndrome among medical students, assessment, prevention and proper management.

Thus, the present study aims to estimate the prevalence of burnout syndrome, explore the association between different variables and burnout syndrome in addition to determining the predictors of burnout syndrome among medical students of Cairo University.

\section{Method}

Study design: A cross-section descriptive study. Study setting: This study was conducted in the Faculty of Medicine (KasrAlaini) - Cairo University. Study period: The study was conducted over a time period of 1.5 years from March 2016 till the end of October 2017. Data collection was performed spaced out from exams' times (taking into consideration the different examination timings of the different grades)

Participants: Newly joining students (first year), Preclinical studies (fourth year), Clinical studies ( $5^{\text {th }}$ and sixth years). It was better to include students from all years. However, it was hypothesized that the $2^{\text {nd }}$ and $3^{\text {rd }}$ year students would not differ greatly from 
the $1^{\text {st }}$ year students and this also applies to the $5^{\text {th }}$ and $6^{\text {th }}$ year students.

Eligibility criteria: Any student who is willing to participate after giving verbal consent. Exclusion criteria:Any student who is suffering from any psychological disease or receiving medical treatment for any psychological disturbance.

Sampling:The sample size is calculated using Open Epi sample size calculator. (http://www.openepi.com/SampleSize/SS

Propor.htm $^{21}$

Setting the Population size at 3600 (It is the total number of the students from the 3 academic years included in the study). The assumed percent of the prevalence of Burnout syndrome in the population is $27 \%$ (an average of different studies report that it ranges from $10 \%$ to $45 \%)^{2,10}$ The Confidence Level was $95 \%$, the Study Power was set at $80 \%$ and the sample size was 280 students. (We calculate it as a guide to the least sample size that should be included and by adding a proposed dropout $25 \%$ we reached the number 350 ).

A convenience non-probability sample of 350 students was recruited to the study from the 1st, 4th and 6th academic years. The 1st academic year students were approached during different academic rounds e.g. Anatomy, Physiology...etc) (trying to represent the students throughout the academic year, apart from the exams timing).Students where approached twice per month, till recruiting a convenient sample of 115 students

The $4^{\text {th }}$ academic year students were approached in the Public Health Department during the Community Medicine Educational round. We targeted a convenient sample of 120 students to be recruited. Taking into consideration that the round is repeated 4 times per academic year, we approached students once per week during each round, till recruiting 30 students per round (trying to represent the students throughout the academic year, apart from the exams timing).
The $6^{\text {th }}$ academic year students were divided into 2 groups based on their clinical educational rounds (Internal medicine and Surgery round). They were approached twice per month till recruiting a convenient sample of 115 students (who were willing to participate).

Written informed consent was obtained from the students prior to their enrollment in the study after explaining the purpose and objectives of the study. Only those who gave informed consent were enrolled to the study. This process was continued till we had 350 students (an estimated sample size).

Out of the 350 questionnaires, only 320 questionnaires were returned to the researcher and 24 of which were excluded as they included incomplete answers. The response rate is $91.4 \%$. 296 students (males and females) completed the questionnaires.

Study tools: All the used study tools were in English. An anonymous structured self-administrated questionnaire was designed to collect the Data. All questions were close ended and were precoded prior to data collection to facilitate data entry and analysis. The questionnaire included two main sections.

The First Section included data about the following: Socio-demographic characteristics, including gender, occupation, residency, etc, lifestyle habits, and adequate explanations were given to the participants for all questions, physically active; based on the definition of WHO of physical activity. ${ }^{22}$ Adequate sleep, which is defined as "sleeping 7 or more hours per night on a regular basis to promote optimal health". ${ }^{23}$ Scholastic achievement in previous year. Perception of medical career among students regarding choosing a specialty and worrying about future income.

Operational definitions: The term Physically Active is based on the definition of WHO of physical activity which refers to "any bodily movements produced by 
Table 1: Comparison of socio-demographic characteristics of studied students according to scores of the 3 dimensions

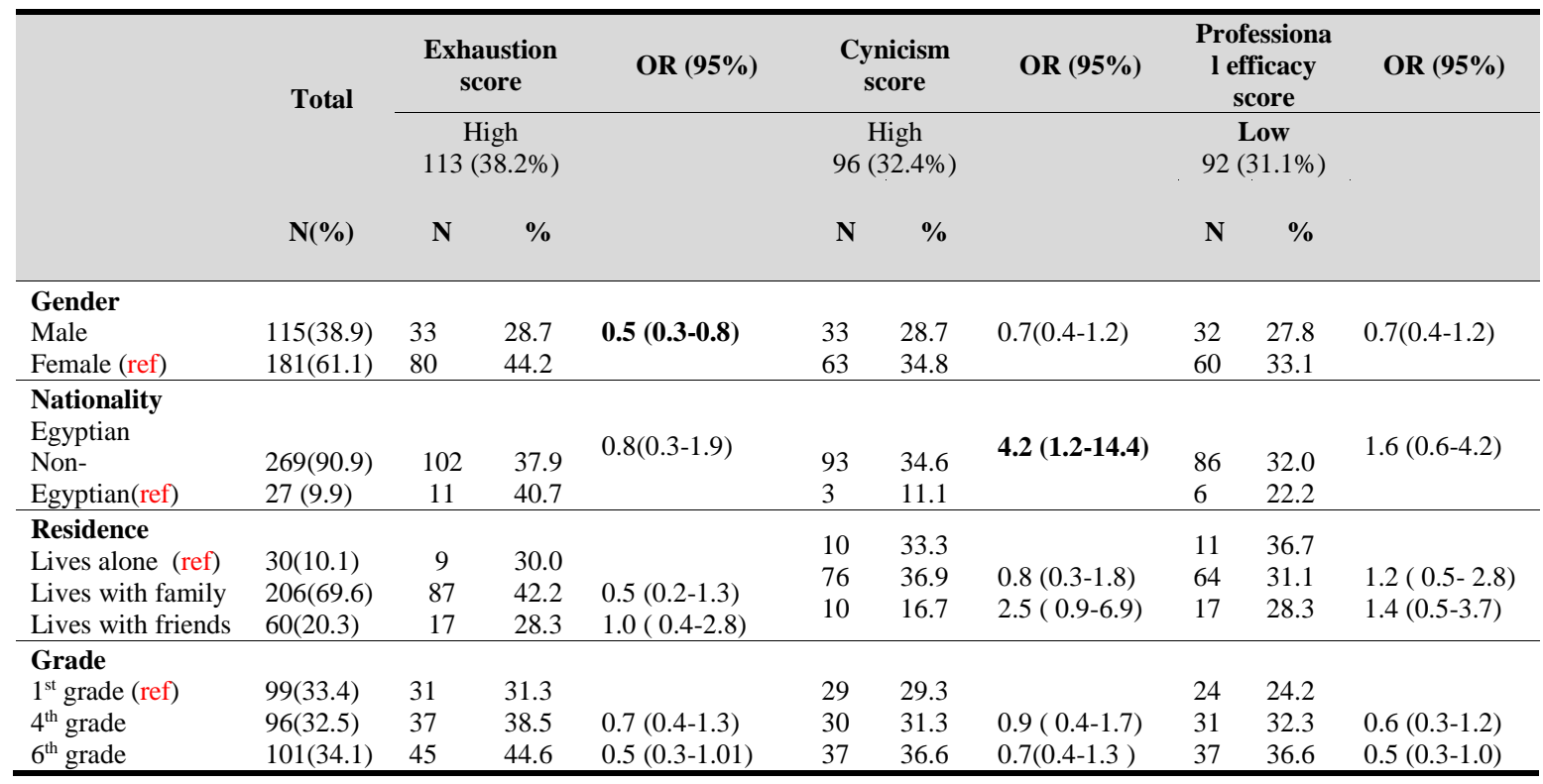

Table 2: Comparison of lifestyle habits of studied students according to scores of the 3 dimensions

\begin{tabular}{|c|c|c|c|c|c|c|c|c|c|c|}
\hline & \multirow{3}{*}{$\begin{array}{l}\text { Total } \\
\text { N (\%) }\end{array}$} & \multirow{2}{*}{\multicolumn{2}{|c|}{$\begin{array}{c}\begin{array}{c}\text { Exhaustion } \\
\text { score }\end{array} \\
\text { High (113) }\end{array}$}} & \multirow[t]{3}{*}{ OR (95\%) } & \multirow{2}{*}{\multicolumn{2}{|c|}{$\begin{array}{c}\begin{array}{c}\text { Cynicism } \\
\text { score }\end{array} \\
\text { High (96) }\end{array}$}} & \multirow{3}{*}{ OR $(95 \%)$} & \multirow{2}{*}{\multicolumn{2}{|c|}{$\begin{array}{c}\begin{array}{c}\text { Professional } \\
\text { efficacy score }\end{array} \\
\text { Low }(92)\end{array}$}} & \multirow[t]{3}{*}{ OR $(95 \%)$} \\
\hline & & & & & & & & & & \\
\hline & & $\mathbf{N}$ & $\%$ & & $\mathbf{N}$ & $\%$ & & $\mathbf{N}$ & $\%$ & \\
\hline $\begin{array}{l}\text { Physical activity } \\
\text { Yes } \\
\text { No(ref) }\end{array}$ & $\begin{array}{l}145(49.0) \\
151(51.0) \\
\end{array}$ & $\begin{array}{l}53 \\
60 \\
\end{array}$ & $\begin{array}{l}36.6 \\
39.7 \\
\end{array}$ & $0.8(0.5-1.39)$ & $\begin{array}{l}39 \\
57 \\
\end{array}$ & $\begin{array}{l}26.9 \\
37.7 \\
\end{array}$ & $0.6(0.3-0.9)$ & $\begin{array}{l}32 \\
60 \\
\end{array}$ & $\begin{array}{l}22.1 \\
39.7 \\
\end{array}$ & $0.4(0.3-0.7)$ \\
\hline $\begin{array}{l}\text { Adequate sleep } \\
\text { Yes } \\
\mathrm{No}(\mathrm{ref})\end{array}$ & $\begin{array}{l}162(54.7) \\
134(45.3)\end{array}$ & $\begin{array}{l}53 \\
60\end{array}$ & $\begin{array}{l}32.7 \\
44.8 \\
\end{array}$ & $0.6(0.3-0.9)$ & $\begin{array}{l}51 \\
45\end{array}$ & $\begin{array}{l}31.5 \\
33.6 \\
\end{array}$ & $0.9(0.5-1.4)$ & $\begin{array}{l}47 \\
45\end{array}$ & $\begin{array}{l}29.0 \\
33.6\end{array}$ & $0.8(0.4-1.3)$ \\
\hline $\begin{array}{l}\text { Eating } \\
\text { breakfast } \\
\text { Yes } \\
\text { No(ref) } \\
\end{array}$ & $\begin{array}{l}107(36.1) \\
189(63.2) \\
\end{array}$ & $\begin{array}{l}36 \\
77 \\
\end{array}$ & $\begin{array}{l}33.6 \\
40.7 \\
\end{array}$ & $0.7(0.4-1.2)$ & $\begin{array}{l}28 \\
68 \\
\end{array}$ & $\begin{array}{l}26.2 \\
36.0 \\
\end{array}$ & $0.6(0.3-1.1)$ & $\begin{array}{l}28 \\
64\end{array}$ & $\begin{array}{l}26.2 \\
33.9\end{array}$ & $0.6(0.4-1.1)$ \\
\hline $\begin{array}{l}\text { Chronic illness } \\
\text { Yes } \\
\text { No(ref) }\end{array}$ & $\begin{array}{c}33(11.1) \\
263(88.9)\end{array}$ & $\begin{array}{l}18 \\
95\end{array}$ & $\begin{array}{l}54.5 \\
36.1\end{array}$ & $2.1(1.1-4.4)$ & $\begin{array}{l}17 \\
79\end{array}$ & $\begin{array}{l}51.5 \\
30.0 \\
\end{array}$ & $2.4(1.1-5.1)$ & $\begin{array}{c}9 \\
83\end{array}$ & $\begin{array}{l}27.3 \\
31.6\end{array}$ & $0.8(0.3-1.8)$ \\
\hline $\begin{array}{l}\text { Smoking } \\
\text { Smokers } \\
\text { Non- } \\
\text { smokers(ref) }\end{array}$ & $\begin{array}{c}17(5.7) \\
279(94.3)\end{array}$ & $\begin{array}{c}7 \\
106\end{array}$ & $\begin{array}{l}41.2 \\
38.0\end{array}$ & $1.1(0.4-3.0)$ & $\begin{array}{c}6 \\
90\end{array}$ & $\begin{array}{l}35.3 \\
32.3\end{array}$ & $1.1(0.3-3.2)$ & $\begin{array}{c}6 \\
86\end{array}$ & $\begin{array}{l}35.3 \\
30.8\end{array}$ & $1.2(0.4-3.4)$ \\
\hline $\begin{array}{l}\text { Leisure time } \\
\text { Yes } \\
\text { No(ref) }\end{array}$ & $\begin{array}{c}89(30.1) \\
207(69.9)\end{array}$ & $\begin{array}{l}24 \\
89\end{array}$ & $\begin{array}{l}27.0 \\
43.0\end{array}$ & $0.4(0.2-0.8)$ & $\begin{array}{l}25 \\
71\end{array}$ & $\begin{array}{l}28.1 \\
34.3\end{array}$ & $0.7(0.4-1.2)$ & $\begin{array}{l}20 \\
72\end{array}$ & $\begin{array}{l}22.5 \\
34.8\end{array}$ & $0.5(0.3-0.9)$ \\
\hline
\end{tabular}

skeletal muscles that require energy expenditure including activities undertaken while working, playing, carrying out household chores, traveling and engaging in recreational pursuits." For adults aged (18-64) it should be at least 150 minutes of moderate-intensity physical activity per week or 75 minutes of vigorous-intensity physical activity. ${ }^{22}$ Adequate sleep is defined as "sleeping 7 or more hours per night on a regular basis to promote optimal health". ${ }^{23}$

Second Section included Maslach Burnout Inventory General Survey for Students (MBI-GS). ${ }^{24}$

MBI-HSS assesses the three dimensions. First, feelings of emotional exhaustion (EE) initiate providers' perception of depleted emotional resources to maintain assisting people. Second, the development of depersonalization (DE) includes the negative mocking feelings 
providers have towards patients or colleagues. However, during the third phase, perception of declined satisfaction or significance of the accomplished tasks leads to diminished personal accomplishment (PS). The MBI calculates the prevalence of Burnout based on the sum of the scores for each dimension. $^{25}$

Table 3: Comparison of scholastic performance of studied students according to scores of the 3 dimensions

\begin{tabular}{|c|c|c|c|c|c|c|c|c|c|c|}
\hline & \multirow[t]{2}{*}{ Total } & \multicolumn{2}{|c|}{$\begin{array}{c}\text { Exhaustion } \\
\text { score }\end{array}$} & \multirow[t]{2}{*}{ OR $(95 \%)$} & \multicolumn{2}{|c|}{$\begin{array}{c}\text { Cynicism } \\
\text { score }\end{array}$} & OR (95\%) & \multicolumn{2}{|c|}{$\begin{array}{c}\text { Professional } \\
\text { efficacy } \\
\text { score }\end{array}$} & OR $(95 \%)$ \\
\hline & & \multicolumn{2}{|c|}{ High (113) } & & \multicolumn{2}{|c|}{ High (96) } & \multicolumn{4}{|c|}{ Low (92) } \\
\hline & $\mathbf{N}(\%)$ & $\mathbf{N}$ & $\%$ & & $\mathbf{N}$ & $\%$ & & $\mathbf{N}$ & $\%$ & \\
\hline \multicolumn{11}{|c|}{ Attending classes in college } \\
\hline Yes & 197(66.6) & 63 & 32.0 & \multirow[t]{2}{*}{$0.4(0.2-0.7)$} & 54 & 27.4 & \multirow[t]{2}{*}{$0.5(0.3-0.8)$} & 52 & 26.4 & \multirow[t]{2}{*}{$0.5(0.3-0.8)$} \\
\hline No(ref) & $99(33.4)$ & 50 & 50.5 & & 42 & 42.4 & & 40 & 40.4 & \\
\hline \multicolumn{11}{|c|}{ Attending private classes } \\
\hline Yes & $117(39.5)$ & 50 & 42.7 & \multirow[t]{2}{*}{$1.3(0.8-2.2)$} & 43 & 36.8 & \multirow[t]{2}{*}{$1.3(0.8-2.3)$} & 37 & 31.6 & \multirow{2}{*}{$1.0(0.6-1.7)$} \\
\hline No(ref) & $179(60.5)$ & 63 & 35.2 & & 53 & 29.6 & & 55 & 30.7 & \\
\hline \multirow{3}{*}{$\begin{array}{l}\text { Scholastic achievemen } \\
(\mathbf{n}=\mathbf{1 9 7}) \\
\text { Excellent/ Very Good } \\
\text { Good/ Accepted(ref) }\end{array}$} & & & & \multirow{3}{*}{$1.1(0.6-1.7)$} & & & & & & \multirow{3}{*}{$1.0(0.6-1.6)$} \\
\hline & $160(34)$ & 63 & 39.4 & & 53 & 33.1 & $0.9(0.5-1.5)$ & 50 & 31.3 & \\
\hline & $136(46)$ & 50 & 36.8 & & 43 & 31.6 & & 42 & 30.9 & \\
\hline
\end{tabular}

The MBI-GS is a 16-item questionnaire

that assesses three core aspects of the

burnout syndrome: Exhaustion (5 items),

Cynicism (5 items), and lack of

Table 4: Comparison of perception about medical career of studied students according to scores of the 3 dimensions

\begin{tabular}{|c|c|c|c|c|c|c|c|c|}
\hline & \multirow{2}{*}{$\begin{array}{l}\text { Total } \\
\text { N }(\%)\end{array}$} & $\begin{array}{c}\text { Exhaustion } \\
\text { score } \\
\text { High }(113)\end{array}$ & \multirow[t]{2}{*}{ OR (95\%) } & \multicolumn{2}{|c|}{$\begin{array}{l}\text { Cynicism } \\
\text { score } \\
\text { High }(96)\end{array}$} & \multirow[t]{2}{*}{ OR (95\%) } & $\begin{array}{c}\text { Professional } \\
\text { efficacy score } \\
\text { Low }(92)\end{array}$ & \multirow[t]{2}{*}{ OR (95\%) } \\
\hline & & $\%$ & & $\mathbf{N}$ & $\%$ & & $\%$ & \\
\hline $\begin{array}{l}\text { Entering college on personal } \\
\text { conviction } \\
\text { Yes } \\
\text { No(ref) } \\
\end{array}$ & $\begin{array}{l}239 \\
(80.7) \\
57(19.3) \\
\end{array}$ & $\begin{array}{l}37.7 \\
40.4\end{array}$ & $0.8(0.4-1.6)$ & $\begin{array}{l}81 \\
15 \\
\end{array}$ & $\begin{array}{l}33.9 \\
26.3\end{array}$ & $1.4(0.7-2.4)$ & $\begin{array}{l}29.7 \\
36.8\end{array}$ & $0.7(0.3-1.3)$ \\
\hline $\begin{array}{l}\text { Helpful home environment } \\
\text { Yes } \\
\text { No(ref) }\end{array}$ & $\begin{array}{l}202 \\
(68.2) \\
94(31,8) \\
\end{array}$ & $\begin{array}{l}38.6 \\
37.2 \\
\end{array}$ & $1.0(0.6-1.7)$ & $\begin{array}{l}64 \\
32 \\
\end{array}$ & $\begin{array}{l}31.7 \\
34.0\end{array}$ & $\begin{array}{l}0.8 \quad(0.5- \\
1.5)\end{array}$ & $\begin{array}{l}28.2 \\
37.2 \\
\end{array}$ & $0.6(0.3-1.1)$ \\
\hline $\begin{array}{lll}\text { Worry about } & \text { choosing } \\
\text { specialty } & & \\
\text { Yes } & & \\
\text { No(ref) } & & \\
\end{array}$ & $\begin{array}{ll}211(71.3) & 94 \\
85(28.7) & 19\end{array}$ & $\begin{array}{l}44.5 \\
22.4\end{array}$ & $2.7(1.5-4.9)$ & $\begin{array}{l}82 \\
14\end{array}$ & $\begin{array}{l}38,9 \\
16.5\end{array}$ & $3.2(1.7-6.1)$ & $\begin{array}{l}35.5 \\
20.0\end{array}$ & $2.2(1.2-4.0)$ \\
\hline $\begin{array}{l}\text { Worry about future income } \\
\text { Yes } \\
\text { No(ref) }\end{array}$ & $\begin{array}{ll}190(64.2) & 85 \\
106(35.8) & 28 \\
\end{array}$ & $\begin{array}{l}44.7 \\
26.4 \\
\end{array}$ & $2.2(1.3-3.7)$ & $\begin{array}{l}75 \\
21 \\
\end{array}$ & $\begin{array}{l}39.5 \\
19.8 \\
\end{array}$ & $2.6(1.5-4.6)$ & $\begin{array}{l}38.4 \\
17.9 \\
\end{array}$ & $2.8(1.6-5.0)$ \\
\hline $\begin{array}{l}\text { Professional Effica } \\
\text { frequency with wh } \\
\text { experiences feeling } \\
\text { aspect is assessed } \\
\text { Likert scale. Each a } \\
\text { Mindgarden. Resp } \\
\text { items should not be } \\
\text { single "burnout" sco } \\
\text { burnout is reflectec } \\
\text { Exhaustion and Cyn } \\
\text { on Professional Effic } \\
\text { The authors used } \\
\text { system }{ }^{26} \text { to classify }\end{array}$ & $\begin{array}{l}\text { (6 item } \\
\text { ich the res } \\
\text { ising a sev } \\
\text { pect is mea } \\
\text { nses to } \\
\text { combined t } \\
\text { e. A high d } \\
\text { in high sc } \\
\text { cism and lo } \\
\text { acy. } \\
\text { the same } \\
\text { burnout wl }\end{array}$ & $\begin{array}{l}\text { ). T } \\
\text { ponde } \\
\text { o ea } \\
\text { en-po } \\
\text { ured } \\
\text { MBI-( } \\
\text { form } \\
\text { egree } \\
\text { ores } \\
\text { scor } \\
\text { scori } \\
\text { ich } \mathrm{W}\end{array}$ & & $\begin{array}{l}\text { a } \\
\text { inte } \\
\text { MB } \\
\text { pers } \\
\text { are } \\
\text { mor } \\
\text { was } \\
\text { the } \\
\text { exh } \\
\text { pro } \\
\text { corı } \\
\text { exh } \\
\text { perc }\end{array}$ & $\begin{array}{l}\text { epara } \\
\text { rprete } \\
\text { I-GS } \\
\text { pecti } \\
\text { basec } \\
\text { e cor } \\
\text { iden } \\
\text { fo } \\
\text { austic } \\
\text { essio } \\
\text { espor }\end{array}$ & $\begin{array}{l}\text { e scale } \\
\text { separate } \\
\text { provide } \\
\text { e on bu } \\
\text { on the } \\
\text { venient it } \\
\text { ified at a } \\
\text { lowing } \\
\geq 27 \text {, } \\
\text { lal effica } \\
\text { ded to th } \\
\text { and cyn } \\
\text { of efficac }\end{array}$ & $\begin{array}{l}\text { and calcu } \\
\text { ly. The sca } \\
\text { a } 3-d \\
\text { rnout, and, } \\
\text { scoring gui } \\
\text { this study } \\
\text { high level } \\
\text { scores: } \\
\text { cynicism } \\
\text { ey } \leq 16 \text {. Th } \\
\text { le } 66 \text { th pe } \\
\text { icism and } t \\
\text { y. }\end{array}$ & $\begin{array}{l}\text { lated and } \\
\text { les of the } \\
\text { mensional } \\
\text { therefore, } \\
\text { delines by } \\
\text {. Burnout } \\
\text { based on } \\
\text { emotional } \\
\geq 20 \text {, and } \\
\text { ese scores } \\
\text { centile of } \\
\text { o the } 33 \mathrm{rd}\end{array}$ \\
\hline
\end{tabular}


Table 5: Significant predictors of the three main components of Burnout Syndrome

\begin{tabular}{|c|c|c|c|}
\hline & AOR & $95 \% \mathrm{CI}$ & P value \\
\hline \multicolumn{4}{|l|}{ Emotional Exhaustion } \\
\hline Worry about choosing specialty(ref: no) & 2.387 & $1.281-4.450$ & 0.006 \\
\hline Worry about future income(ref: no) & 1.960 & $1.093-3.513$ & 0.024 \\
\hline Gender(ref: females) & -0.471 & $0.275-0.809$ & 0.006 \\
\hline Attending classes in college(ref: no) & -0.416 & $0.245-0.706$ & 0.001 \\
\hline \multicolumn{4}{|l|}{ Cynicism } \\
\hline Chronic illness(ref: no) & 2.918 & $1.305-6.522$ & 0.009 \\
\hline Worry about choosing specialty(ref: no) & 2.255 & $1.199-4.242$ & 0.012 \\
\hline Worry about future income(ref: no) & 1.873 & $1.056-3.323$ & 0.032 \\
\hline Attending classes in college(ref: no) & -0.500 & $0.294-0.852$ & 0.011 \\
\hline \multicolumn{4}{|l|}{ Low Professional Efficacy } \\
\hline Worry about future income(ref: no) & 5.577 & $2.370-13.120$ & 0.000 \\
\hline Physical activity (ref: no) & -0.274 & $0.138-0.543$ & 0.000 \\
\hline Attending classes in college(ref: no) & -0.390 & $0.189-0.804$ & 0.011 \\
\hline
\end{tabular}

This inventory was used under the license of Mind Garden and was purchased via their website (www.mindgarden.com)

\section{Data Management and Analysis:}

All the data were revised for completeness and logical consistency. Pre-coded data were entered into the computer using Microsoft Office Excel software for Windows 2010. Data were then transferred to the statistical package of social science software, Version 21 (SPSS) to be statistically analyzed. Simple frequencies were used for data checking. Descriptive statistics were used for data summarization. Quantitative data were presented using mean and SD for normally distributed and median data with inter quartile range for non-normally distributed data. Bivariate relationships were displayed in cross tabulation. The $\mathrm{T}$ test and Chi Square test were appropriately used to compare between the groups. The least statistical significance level used was at $\mathrm{P} \leq 0.05$.

Multivariate logistic regression analysis was carried out by using stepwise forward modeling (probability of $\mathrm{F}$ to enter $=0.05$ and probability of $\mathrm{F}$ to remove $=0.10$ ) to detect predictors of different dimensions of Burnout Syndrome. Only the variables which showed significant association in bivariate analysis were entered in the model.

\section{Ethical Consideration:}

The study was conducted after explaining the steps of the study and its objectives to the participants. Only those who agreed to take part were included and those who refused were excluded. Verbal consent was obtained from all the participants in the study according to Helsinki Declarations of Biomedical Ethics $^{27}$ and after getting approval from the head of the Community Medicine and Public Health Department and Vice Dean for Undergraduates. Approval of the Ethical Committee for Research affiliated to the Public Health Department was also obtained.

\section{Results:}

The association between sociodemographic characteristics and three burnout dimensions showed that high exhaustion is significantly $50 \%$ less likely to occur in males than in females ( $28.7 \%$ vs. $44.2 \%$, respectively). High cynicism score is significantly $80 \%$ less likely to occur among non-Egyptian students than the Egyptian ones $(\mathrm{OR}=0.2)$. On the other hand, there is no significant difference in terms of Professional efficacy regarding the sociodemographic characteristics of the respondents.

Distribution by grade showed that the 6th year students represent the highest prevalence in all burnout syndrome dimensions compared to the $1 \mathrm{st}$ and 4 th year students. However, there is no statistically significant difference 
between all the students in different years.

Comparison of the life style of students according to the burnout score in Table 2 revealed that $40 \%$ of students who get adequate sleep are significantly less subject to high exhaustion. Students who have leisure time are significantly $60 \%$ less likely to suffer high exhaustion. Non-chronically ill students were significantly $60 \%$ less likely to have higher Cynicism scores. Physically active students and those who spend enough leisure time have significantly high sense of professional efficacy ( $\mathrm{OR}=0.4$ and 0.5 , respectively).

The relationship between scholastic achievements and burnout score is illustrated in Table 3. Attending regular classes in collage is significantly less likely to be associated with high exhaustion score, high cynicism and low professional efficacy $(\mathrm{OR}=0.4$ vs 1.9 vs. 0.5 , respectively).

Worrying about both choosing specialty and future income is significantly associated with low scores in all burnout dimensions (Table 4).

Table 5 explains the significant predictors of the three main components of Burnout Syndrome. It shows that when it comes to Exhaustion, students who worry about choosing their specialty as well as their future income are almost two times more prone to high exhaustion than those who do not. With regard to gender, male students are less subject to high exhaustion than female students by almost $50 \%$.

This table also explains the significant predictors of High Cynicism score. Students who suffer from chronic diseases are almost three times more prone to having High Cynicism score. Worrying about choosing a specialty and future income increases the risk of having high cynicism two times. Regarding Low Professional Efficacy, the most important factor is worrying about future income that increases its risk five times. Being physically active helps students to feel $75 \%$ more professionally efficient.

Attending classes regularly in college protects against all three components of Burnout Syndrome and decreases their risk by nearly $50 \%$.

\section{Discussion}

It is incontestable that for those who have tolerated medical schooling, excess workload, lack of support, and loss of control at times contributed to a sense of emotional exhaustion, and some may be fed up with such lifestyle. Sentiment of diminished individual achievement, exhaust, and passionate responsibility towards studying medicine can prompt depersonalization (Cynicism). These are the main components of burnout syndrome. ${ }^{28}$ Coming across the Maslach Burnout subscales, this study, nonsurprisingly, showed that $38.1 \%$ of the studied population experienced high emotional exhaustion subscale conforming to Gabbe et al., (2002) findings'. ${ }^{29}$ It was also stated that $88 \%$ of the third year medical students had moderate to high emotional exhaustion, due to excessive workload, along with sense of dependence and ill management of work environment.

Furthermore, the present study highlighted the fact that high exhaustion is significantly $50 \%$ less likely to occur in males than in females $(28.7 \%$ vs. $44.2 \%$, respectively). Backović et al., (2012) and Fawzy \& Hamed (2017) focused on the same interpretation that females commonly experience lower threshold to stressors rather than exposure to more stressors as compared to male students. Females have many social roles outside the school that waste the energy and time necessary for learning and resting, which could be the reason for more burnout among them. ${ }^{30,31}$ Additionally, it is highlighted that the $6^{\text {th }}$ year students represent the highest prevalence in all burnout syndrome 
dimensions compared to the 1st and 4th year students. However, there is no statistically significant difference between all the students in different years.

This result came in consistence with the results reached by Melaku et al., (2015) ${ }^{32}$ who studied Burnout among 329 medical students at Jimma University in Ethiopia and had stated that burnout increases as students enter more advanced phases of medical education.

Regular physical exercise brings about improved sense of self-control, greater social interaction and credible positive implications for mental health. ${ }^{33}$ This could elucidate the remarkable lower levels in burnout dimensions established among the physically active students in the present study. In the same context, several studies affirmed a strong association between inadequate sleep and high burnout subscales in the 3 dimensions ${ }^{34,35}$, which came in agreement to the present study findings. This could be explained by the fact that Insomnia has been considered an early marker of some psychiatric disorders, such as depression and anxiety. ${ }^{35}$

Also, Cecil et al. (2014) stated that higher levels of Emotional Exhaustion and Cynicism were reported by students who make poor dietary choices and skip meals as a coping mechanism for mental distress. $^{36}$ In the present study, the students who get adequate sleep are significantly $40 \%$ less to suffer high exhaustion.

Lack of leisure time for recreational or extracurricular activities was significantly associated with high Emotional Exhaustion $(\mathrm{p}=0.009)$ and low Professional Efficacy $(\mathrm{p}=0.036)$. This finding was supported by several studies that concluded that lack of time for recreation in the institution is a chief source of stress; one study determined the prevalence of Burnout Syndrome among 376 medical students in Brazil and another was conducted in India on
750 medical undergraduate students in a private medical college. ${ }^{37,38}$

However, attending college classes on a regular basis was found to guard against developing any of burnout dimensions. This was in harmony with the literature that accentuates the association between lack of college support and high burnout scores. $^{39}$

Using Regression analysis, it was illustrated that the most significant predictors of high burnout subscales were worrying about the future income and choosing specialty and this accords with previous studies. ${ }^{40}$ Moreover, suffering from chronic diseases was affirmed to be a significant predictor for Cynicism and traveling a long way to get to the college significantly lowers Professional Efficacy, and this also supports the previous literature findings. ${ }^{31,39}$

\section{Conclusion:}

These results show the requirement for mental support for medical students and the impending need for longitudinal studies on this point in our organization and in different organizations with comparable profiles.

Limitations: Cross-sectional design in our study limited establishing a causal relationship among the associations we recognized. Not all educational years were included and this is an important issue to be tackled in the future. Lack of standardization of the MBI-GS questionnaire diagnostic criteria in other studies, together with the intrinsic differences in the infrastructure and medical models in different studies make it difficult to generalize these results into other contexts.

\section{Acknowledgment}

Words cannot express our gratitude to all the students who were included in the study for their help, which was crucial for the facilitation of the practical work in this thesis. 


\section{References}

1. Dyrbye L, Thomas M, Shanafelt T. Medical student distress: Causes, consequences, and proposed solutions. Mayo Clin Proc. 2005;80:1613-22.

2. Aguiar SM, Vieira APGF, Vieira KMF, Aguiar SM, Nobrega JO. Prevalencia de sintomas de estressenosestudantes de medicina. J Bras Psiquiatr. 2009; 058(1):3428.

3. Furtado ES, Falcone EMO, Clark C. Avaliacao do estresse e das habilidades

4. sociaisnaexperienciaacademica de estudantes de medicina de uma

5. universidade do Rio de Janeiro. InteracaoemPsicologia. 2003;7(2):43-51

6. Steward S, Lam T, Betson C, Wong C, Wong A. A prospective analysis of stress and academic performance in the first two years of medical school. Med Educ. 1999;33:243-50.

7. Maslach C, Jackson SE, Lieter MP. Maslach Burnout Inventory Manual. ed 3. Palo Alto, CA, Consulting Psychologists Press, 1996

8. De Oliveira Jr GS, Chang R, Fitzgerald PC, Almeida MD, Castro-Alves LS, Ahmad $S$, et al. The prevalence of burnout and depression and their association with adherence to safety and practice standards: a survey of United States anesthesiology trainees. AnesthAnalg. 2013;117(1):182-93.

9. Gabbe SG, Melville J, Mandel L, et al. Burnout in chairs of obstetrics and gynecology: diagnosis, treatment and prevention. Am J ObstetGynecol 2002;186:601- 612

10. SpickardA Jr, Gabbe SG, Christensen JF. Mid-career burnout in generalists and specialist physicians. JAMA 2002;288:1447-1450.

11. De Oliveira Jr GS, Ahmad S, Stock MC, Harter RL, Almeida MD, Fitzgerald PC, et al. High incidence of burnout in academic chairpersons of anesthesiology: should we be taking better care of our leaders Anesthesiology. 2011;114 (1):181-93.

12. De Oliveira Jr GS, Chang R, Fitzgerald PC, Almeida MD, Castro-Alves LS, Ahmad $\mathrm{S}$, et al. The prevalence of burnout and depression and their association with adherence to safety and practice standards: a survey of United States anesthesiology trainees. AnesthAnalg. 2013;117(1):182-93

13. Prins JT, Hoekstra-Weebers JEHM, Gazendam-Donofrio SM, Dillingh GS, Bakker AB, Huisman M, et al. Burnout and engagement among resident doctors in the Netherlands: a national study. Med Educ. 2010;44(3):236-47.

14. Ferreira Ndo N, de Lucca SR (2015) Burnout syndrome in nursing assistants of a public hospital in the state of São Paulo. Rev Bras Epidemiol 18: 68-79. 4.

15. Navarro-González D, Ayechu-Díaz A, Huarte-Labiano I (2015) Prevalence of burnout syndrome and factors associated with this syndrome in primary care health professionals. Semergen-Med Fam 41: 191198

16. Maite V, Muñoz CC, Pernas FO, Sureda JC, Lopez MPG, et al. (2015) Burnout and teamwork in primary care teams. Aten Prim 47: $25-31$

17. Benevides-Pereira AMT, Goncalves MB. Transtornosemocionais e aformaca oemmedicina: um estudo longitudinal. Rev Bras Educ Med.2009;33(1):10-23.

18. Costa O., Santos S A., Santos AT,I Melo EV, Andrade TM, Burnout Syndrome and associated factors among medical students: a cross-sectional study CLINICS 2012;67(6):573-579

DOI:10.6061/clinics/2012(06)05 573

19. Dyrbye LN, Thomas MR, Huntington JL, Lawson KL, Novotny PJ, Sloan JA, et al. Personal life events and medical student burnout: a multicenter study. Acad Med. 2006;81(4):374-84.

20. Carlotto MS, Camara SG. Preditores da sindrome de burnout emestudantesuniversitarios.

PensamentoPsicologico. 2008;4 (10):101-9. 21. Melamed S, Shirom A, Toker S, Berliner S, Shapira I. Burnout and risk of cardiovascular disease: evidence, possible causal paths, and promising research directions. Psychol Bull. 2006;132(3):32767.

22. Maslach C, Leiter MP. Understanding the burnout experience: recent research and its implications for psychiatry World Psychiatry 2016;15:103-111.

23. Open Episample size calculator available at http://www.openepi.com/SampleSize/ SSPropor.htm 


24. WHO fact sheet (2017)

http://www.who.int/news-room/fact-

sheets/detail/physical-activity

25. Badr MS, Belenky G, Bliwise DL, Buxton OM, Buysse D, Dinges DF, Gangwisch J, Grandner MA, Kushida C, Malhotra RK, Martin JL. Recommended Amount of Sleep for a Healthy Adult: A Joint Consensus Statement of the American Academy of Sleep Medicine and Sleep Research Society. Journal of Clinical Sleep Medicine. 2015 Jun 15;11(06):591-2.

26. Maslach C, Jackson SE. The measurement of experienced burnout. Journal of organizational behavior. $1981 \mathrm{Apr}$ 1;2(2):99-113.

27. .Maslach C, Schaufeli WB, Leiter MP. Job Burnout. Annu Rev Psychol. 2001;52(1):397-422

28. Costa EF, Santos SA, Santos AT, Melo EV, Andrade TM. Burnout Syndrome and associated factors among medical students: a cross-sectional study. Clinics. 2012; 67(6):573-80

29. General Assembly of the World Medical Association. World Medical Association Declaration of Helsinki: ethical principles for medical research involving human subjects. J Am Coll Dent. 2014 Summer;81(3):14-8.

30. Santen S.A., Holt D.B, Kemp J. D., and Hemphill R.R."Burnout in Medical Students: Examining the Prevalence and Associated Factors" Southern Medical Association. 2010;103:8.

31. Gabbe SG, Melville J, Mandel L. Burnout in chairs of obstetrics

32.and gynecology: diagnosis, treatment and prevention. Am J Obstet Gynecol. 2002;186:601-612.

33. Backović DV, IlićŽivojinović J, Maksimović J, Maksimović M. Gender differences in academic stress and burnout among medical students in final years of education. PsychiatriaDanubina. 2012 Jun 24;24(2.):175-81.

34. Fawzy M, Hamed SA. Prevalence of psychological stress, depression and anxiety among medical students in Egypt. Psychiatry research. 2017 Sep 1;255:186-94.

35. Melaku L, Mossie A and NegashA. Stress among Medical Students and Its Association with Substance Use and Academic Performance Journal of Biomedical Education. 2015. http://dx.doi.org/10.1155/2015/149509
36. Weight CJ, Sellon JL, Lessard-Anderson CR, Shanafelt TD, Olsen KD, Laskowski ER. Physical activity, quality of life, and burnout among physician trainees: the effect of a team-based, incentivized exercise program. InMayo Clinic Proceedings 2013 Dec 1, 88(12): 1435-1442

37. Chang PP, Ford DE, Mead LA, CooperPatrick L, Klag MJ. Insomnia in young men and subsequent depression: The Johns Hopkins Precursors Study. American journal of epidemiology. 1997 Jul 15; 146(2):10514. Wolf MR, Rosenstock JB. Inadequate sleep and exercise associated with burnout and depression among medical students. Academic psychiatry. 2017 Apr 1;41(2):1749

38. Cecil J, McHale C, Hart J, Laidlaw A. Behaviour and burnout in medical students. Medical education online. 2014 Jan 1;19(1):25209

39. Almeida GD, Souza HR, Almeida PC, Almeida BD, Almeida GH. The prevalence of burnout syndrome in medical students. Archives of Clinical Psychiatry (São Paulo). $2016 \mathrm{Feb}$;3(1):6-10.

40. Anuradha R, Dutta R, Raja JD, Sivaprakasam P, Patil AB. Stress and stressors among medical undergraduate students: A cross-sectional study in a private medical college in Tamil Nadu. Indian journal of community medicine: official publication of Indian Association of Preventive \& Social Medicine. 2017 Oct;42(4):222.

41.Roh MS, Jeon HJ, Kim H, Han SK, Hahm BJ. The prevalence and impact of depression among medical students: a nationwide cross-sectional study in South Korea. Acad Med. 2010; 85(8):1384-90, http://dx.doi.org/

42.10.1097/ACM.0b013e3181df5e43. 43. El-Masry R, Ghreiz S M, Helal RM, Ahmed M Audeh, Shams TM. Perceived Stress and Burnout among Medical Students during Clinical Period. Ibnosina Journal of Medicine and Biomedical Sciences. 2012 Oct 24;5(4): 179-1 
